\title{
Archaeological Artifacts at Cultural Village Regionof Kemoning, Klungkung
}

\author{
Ni Wayan Herawathi \\ Faculty of Arts \\ Udayana University \\ Bali, Indonesia \\ Email: niwayanherawathi@gmail.com
}

\begin{abstract}
Abstrak The research toward archaeological artifacts at Cultural Village region of Kemoning aims to reconstruct every aspect of life (history, behavior and cultural process) of society in the past, so that people may recognize, understand, comprehend everything about their villages, growing a confidence on living in villages, and join to participate in cultural preservation step in the future. Cultural village of Kemoning has many archaeological artifacts and cultural/ traditional values which still applied in community. Meanwhile its artifacts, like statues, sacred stones/prehistoric stones, inscriptions made of copper and palm leaves, puppet reliefs in the walls, ancient place of worships (pelinggih), temples' gates (paduraksa and symmetrical arches (candibentar)), creese/spears, etc. Artifacts/statue relics in this village is quite many, with various figures being made statues, among others Trimurti statues (Brahma, Vishnu, Shiva), ascetic statues, Bhatara di gumi statues (statue/manifestation of ancestors of Kemoning village riding horses), naked statues believed as the symbol of fertility/ expectation for babies, pennant statue as god of art (dance, etc.), statues of gods/ goddess, statue of Ganesha, and statues of other figures. Cultural village of Kemoning has many ancient temples, among others: temple of KahyanganTiga, temple of Dang Kahyangan, temples which its location as crossers (penyirang) (northeast, southeast, northwest, and southwest), temples of kawitan, temples of paibon, and many more of shrines (pelinggih/penyiwianbhatara). The position of these temples which show pattern position directing to every corner of compass' point raises hypothesis by the author, that is whether at that time the teaching of SiwaSidhanta had developed? And whether people of Kemoning at that time had recognized the concept of "mandala" in designing/setting their village? Also, to determine what is the best cultural concept to be maintained/developed in the future?. In addition, Kemoning village also has a set of magical ancient gong, subak/ pekaseh system, tradition of magibung, tradition of ngayah, ngupadesa, ngusabanini, and kinship with other communities in other regions. Various ancient contents owned by Kemoning community, therefore it is necessary to be revealed specifically, to be known by people, our offspring and public.
\end{abstract}

Keywords: archaeology, interpretation of ancient history of Kemoning, and preservation.

\section{INTRODUCTION}

To build a big nation then it is not enough just building the physical/material sectors, but must be in balance with building of mental/cultural aspect, so that it is able to grow nation character. To make people to be able to recognize, understand, develop and implement the values of noble culture of its nation into daily life. As being carried out in Cultural Village of Kemoning, Klungkung, nowadays they are searching for the traces of its ancient historical/cultural from the past up to later era.

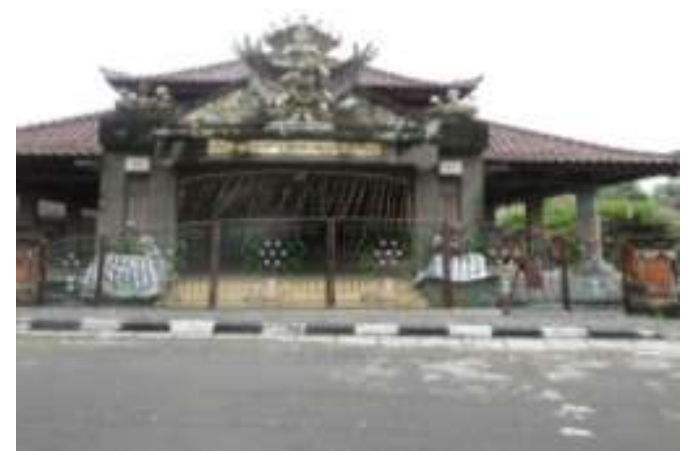

Wantilan at Cultural Village of Kemoning, Klungkung.

Kemoning cultural village is one of villages in Bali which has many archaeological artifacts and 
cultural/traditional values which still being performed by community. It is necessary to focus on revealing its ancientness, to be known by local community/public, researchers and for treasury of archaeological scientific core. The following are multiple samples of archaeological artifacts belongs to Kemoning cultural village, Klungkung.

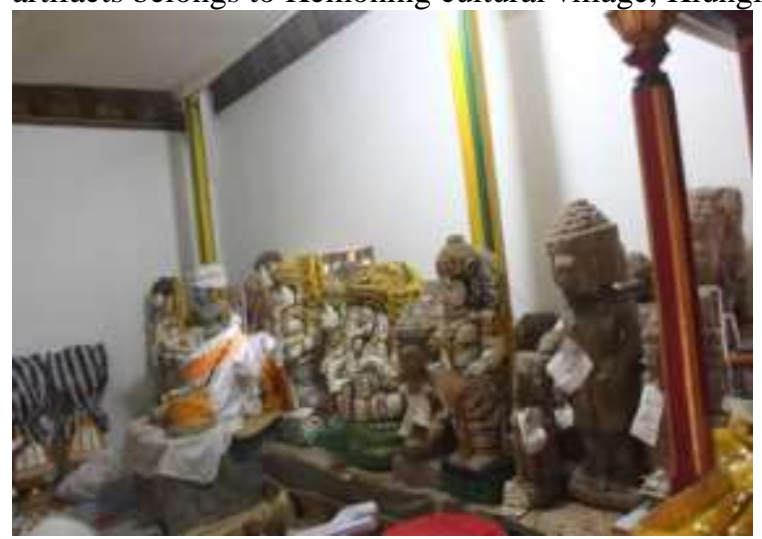

Statues, etc. at Pejenengan Building PusehTemple, Kemoning, Klungkung.

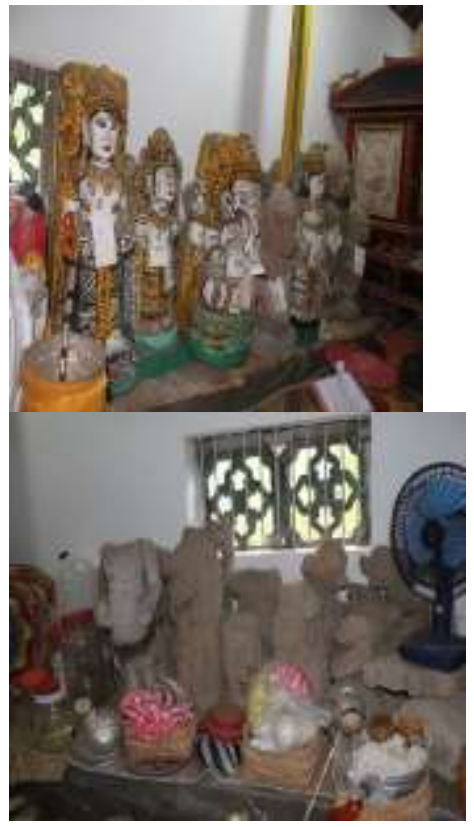

Statues, etc. at Pejenengan Building PusehTemple, Kemoning, Klungkung.

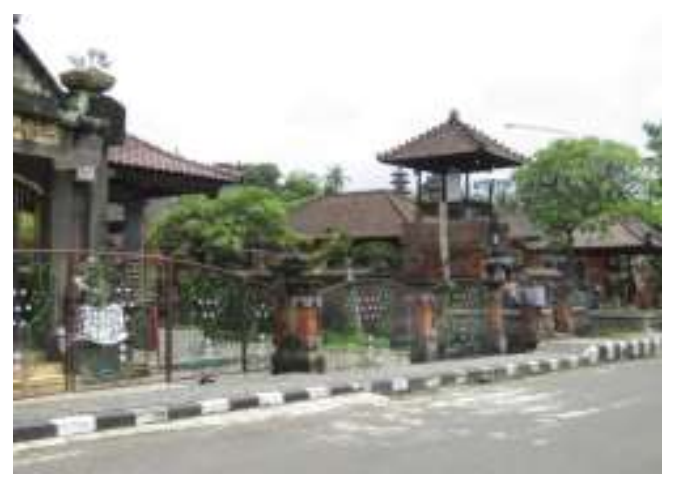

Puseh temple at Kemoning cultural village, Klungkung, southwest side.

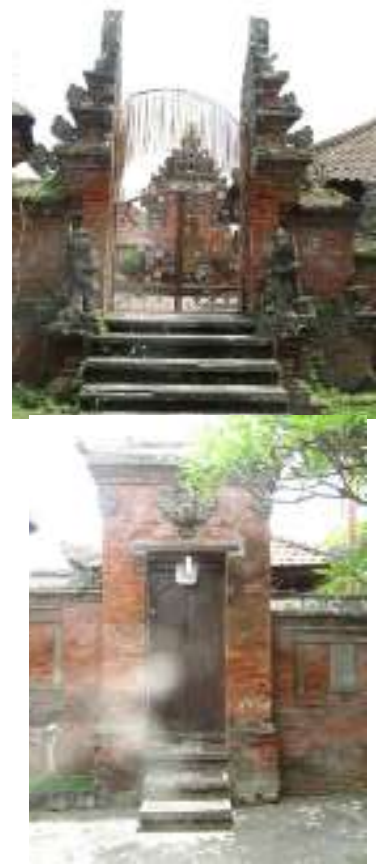

CandiBentar and Paduraksa (big and small), Puseh temple at Kemoning, Klungkung.
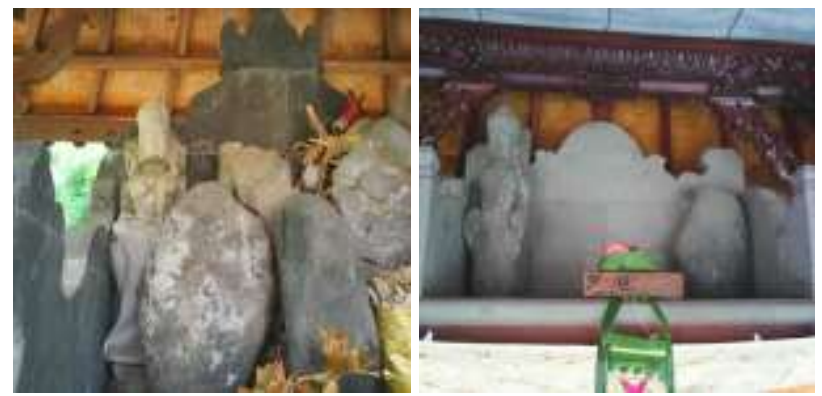

Statue, statue's fragments, and magical natural stones at Petingar temple. Right picture: Statue and statue's fragments at Uluwatu temple, Kemoning, Klungkung.

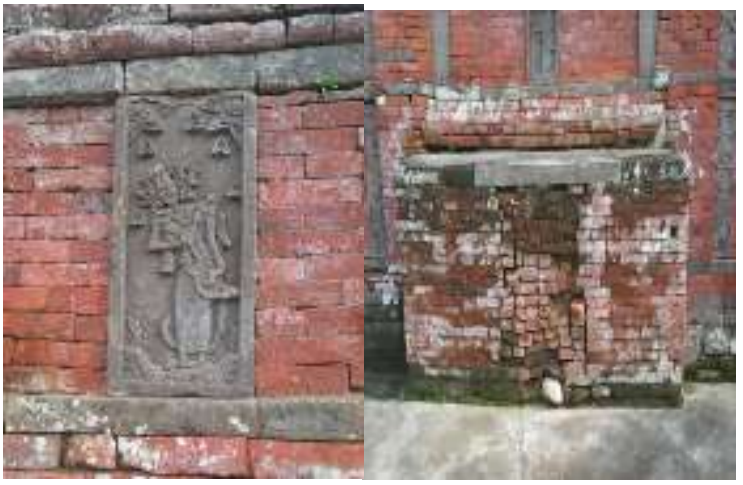


Picture 5 and 6: Puppet relief and original wall (sample) at Uluwatu temple, Kemoning, Klungkung.

\section{RESEARCH METHOD}

Method is related to ways of working to understand objects which become the target of the said science. In a research, the method being selected is adjusted with intention and objective to be achieved. By using correct and systematic method, it is expected to result in a scientific work which can be verified. In an effort to solve the problem mentioned above, the author used several ways/research methods, among others:

Data Collection Method: Implementation of data collection in this research is through multiple ways, namely through literature study, observation and interview. Literature study is data collection from literature/documents which is relevant

with the issue. In this way, it is intended as a footing prior and after conducting a research in the field. Literature study may be in the form of reading books existed in the village, reports, and scientific magazines or any form of publication (Surskhmad, 1981: 47). With literature study, it is expected to find out concept regarding archaeological artifacts/ancientness presence at the region of Kemoning cultural village, Klungkung. In addition to determine basic theory, thinking concept which has been put forward by previous researchers as main sources to be used as consideration in data analysis stage.

Observation is carried out by observing directly research object in the field. Data collection effort with this way is conducted systematically with standard procedure. In this observation, multiple ways are performed namely observation, recording, description, photographing, or if necessary also drawing. Description is both quantitatively and qualitatively (verbal description). Recording (description) toward archaeological artifacts in research area is either in the form of shapes, sizes, colors, and equipped with drawing.

Interview is conducted directly by asking/search for information on informants who know artifacts left in the area.

\section{DAta Processing Method}

Data processing is conducted after all data is collected, namely in the form of analysis, comparative and synthesis. Analysis is performed to all data acquired in prior stage, both primary and secondary data, and later is processed (analyzed) both quantitatively (number) and qualitatively (analysis based on data content or data quality). In addition, in this research the usage of comparative object must be performed to strengthen in synthesis (drawing a conclusion). Synthesis is performed to spark new concept based on similarity element between the whole data, next is to draw conclusion to answer the objective of research or hypothesis which has been predetermined. Conclusion/new theory is just temporary answer which at any time may be reviewed again if it finds data or opinion which is more perfect in the future.

\section{RESULT AND DISCUSSION}

The variety of types of artifacts found in the area of Kemoning cultural village, was motivating the author to study/reconstruct community's life in the past. On the support by LPPM UNUD to give opportunity for the author to make this as one of the top seeded research title of the study program, and in 2017 the author was starting to prepare to actualize the aspiration.

How happy the author during the research that many things were disclosed as reconstruction data of the traces of historic life of the community in the past. It was as if all the data was able to tell the story about all events of the whole era. It was buried, unearthed, and disclosed.

The statues of the figures of gods/goddess/ancestors which were intact numbering 30 pieces of statues (26 statues were stored in Pejenengan Building Temple of PusehKemoning, 1 statue stored in Petingar temple, Kemoning, 2 statues stored in PesimpenanBhataraDalem in Puseh temple Kemoning, and 1 statue in Uluwatu temple, Kemoning). Incomplete statues were numbering 9 pieces in Pejenengan Building Temple of PusehKemoning, and incomplete 2 statues in Petingar temple, Kemoning. The whole statues were ancient statues based on the style of production period prior to Gelgel era. The whole statues showed 3 period stages that the rather bigger statues were classified into Balinese Late Antiquity era by the author, probably between $12^{\text {th }}-13^{\text {th }}$ century AD. Meanwhile the statues which had ancient style but rather smaller, similar size with pretime (symbol of god) then the author classified it into SampranganGelgel era $\left(14^{\text {th }}-16^{\text {th }}\right.$ century). Except there was statue of Bhatara in Gumi riding a horse including the companion of him, and the statue of Acintya which its style was from the era of Samprangan Gelgel.

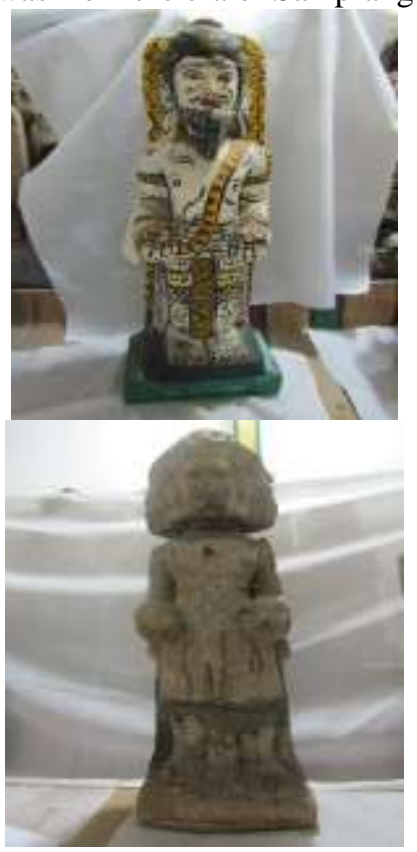


Rsi Rsi Agastya statue, dan Arca Brahma Catur Muka statue at Pejenengan Puseh temple Kemoning Klungkung

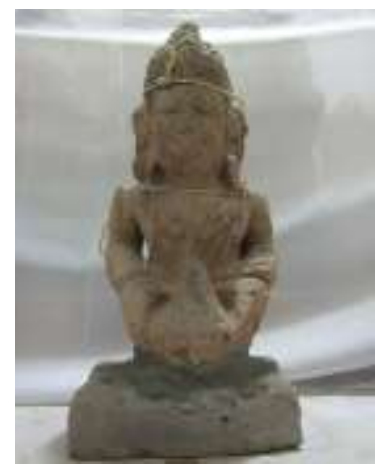

Dewa Wisnu statue at Pejenengan Puseh temple Kemoning.
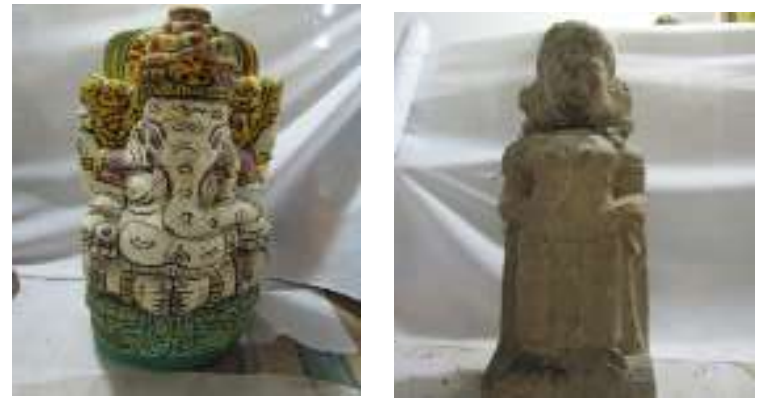

Ganesha statue and Bhatari statue at Pejenengan Puseh temple Kemoning.

Why the author classified it into the era after the reign of King Udayana? It was because its trace showed that this village's ancestors wanted that what was existed atPucakPenulisan temple, Bangli also presence in the temples at Kemoning village. In addition, the material quality was weaker (sandstone/semi andesite) compared to material of statues atPucakPenulisan temple which was from pure andesite stone/stronger. In addition, the statues were rather smaller from the statues existed atPucakPenulisan temple, Bangli. So that it might be interpreted that there was a gap/interval of production era of the statues atPucakPenulisan temple compared to the statues atKemoning village, Klungkung.

Meanwhile the conformity/similarity/resemblance of these statues lied in its clothing and style, moreover its crown showed of the same era and meditation expression with eyes half opened or looked like calmly closed. When imagining the impression of the figures/style of the ancient statues at Kemoning village, it showed similarity/resemblance with the shower figures at Goa Gadjah, Gianyarwhich also in the same era with statues at PucakPenulisan temple, Bangli (periodization of Balinese statues according to Stutterheim). The amazing thing was the presence of phallus at Puseh templeKemoning with sketches in it as a symbol of water outlet, it turned out that it was similar with sketches in the phallus presence at
PucakPenulisan temple. Besides that the shape of Ganesha's statue was similar with the one at PucakPenulisan temple. And the presence of Brahma CaturMuka's statue at Pejenengan Building Temple of PusehKemoning, Klungkung, was similar with CaturMuka's statue at PucakPenulisan temple, Bangli.

Based on the mysteries mentioned above then the author is predicting that the ancestors of Kemoning village made PucakPenulisan temple as a reference for their religious orientation. The author is more convinced that Kemoning village had existed since the era not too far awayafter Udayana era/those writing, around Balinese Late Antiquity era $/ 12^{\text {th }}-13^{\text {th }}$ century AD.

The style of Gelgel statue, Klungkung also exists at Kemoning village, Klungkung, namely the statues exists at shrine (Pelinggih) of Ngrurah Arak Api temple, Kemoning and statue's fragments in front of the gate of Arak Api temple, Kemoning. The author suggests that these statues are part of building architecture which had long separated from its main building. It has been explained before that the front part of Arak Api temple is nearby the river in its eastern part. It means that the building of Arak Api temple had been built when client Pasek came/ setting the village's life in the era after Bali was defeated by Majapahit and stability era during the reign of Gelgel kingdom.

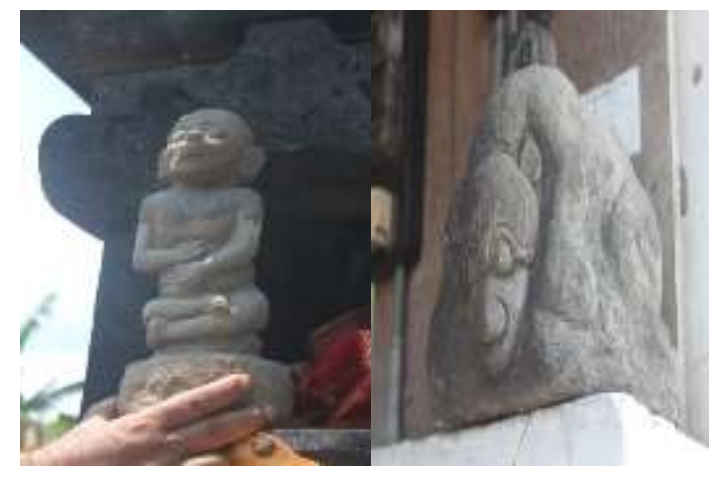

Bhatara statue, dan Nandi statue at Arak Api statue, Kemoning

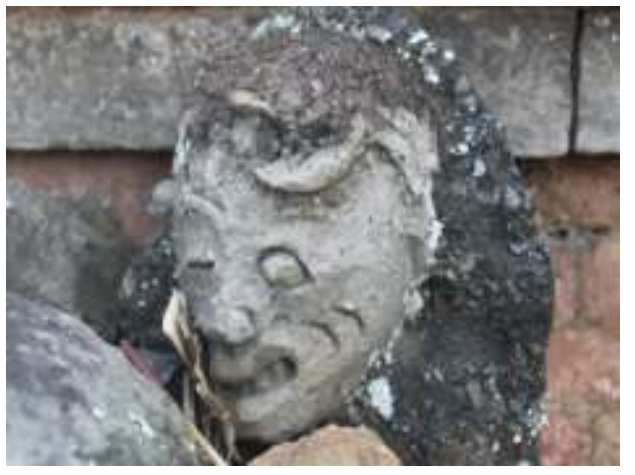

Head fragmen staueat Pura Arak Api statue, Kemoning.

Based on rationale that the wall supporting the temple in the region of Kemoning village originated from the era of 
Gelgel, Klungkung, so all the guarding statues are also from that era too. Including kinara/kinari statues which presence on the side of the shrines. Expressive mimic, ornaments in the form of sumping/subeng are the ornaments in the era of Traditional Balinese (starting from $14^{\text {th }}$ century AD).

The style of statues in the era of Klungkung kingdom also exist at Kemoning village, namely colonial statues/figures of western people which presence at IbuGede temple, Kemoning. Also the statues which size are small and expressive which presence at UlunSwargaIbuGede shrine, Kemoning, aligned with the era of establishment of IbuGede in Klungkung colonial era. At that time if you wanted to build a temple then it should accompanied with Dutch/Portuguese statues.

The statues in this village are quite many, with various figures being made statues, among others Trimurti statues (Brahma, Vishnu, Shiva), ascetic statues, Bhatara di gumi statues (statue/manifestation of ancestors of Kemoning village riding horses), goddess statues, naked statues believed as the symbol of fertility/ expectation for babies, pennant statue as god of art (dance, etc.), statue of Ganesha, Nandi's statue and others.

Something more interesting is that there is unfinished stones/statues namely stones which seemed to be made statue but unfinished. Artifacts like this presence at Pejenengan building numbering 3 pieces, at BhataraDalem shrine in Puseh temple Kemoning as many as 1 pieces, and there is possibility it is also presence at UlunSwargalbuGede shrine, Kemoning, Klungkung.

The function of the statues being studied on the whole shows multiple function, namely aspretime statue/symbol of god such as statues at Pejenengan Building Puseh Temple, Kemoning, god/goddess statues at PesimpanganBhataraDalemPuseh temple, Kemoning, god/goddess statues at Petingar temple, Kemoning and god statues at Uluwatu temple, Kemoning, and others which being used as media when worshipping god. The function of statues as guardian/ dwarapala/kinara-kinariis usually located near the door as the guardian of god. And statues as fragments/part of building architecture, including all the reliefs existed in the supporting wall either telling or not, all of it are the statues in 2 dimension size. It usually functions as cleaning ritual so that shrine being a throne becomes sacred religiously.

Cultural village of Kemoning has many ancient temples, among others; Kahyangantiga temple, Dang kahyangan temple, temples which location as crossers (northeast, southeast, northwest, and southwest), kawitan temples, paibon temples, and many more shrines/worshipping of gods. Every T-junction/ crossroads there exists a shrine/guardian, all of it brings safety to village community.

Position of the temples shows layout in the direction of every corner of compass' point shows that the setting of Kemoning cultural village in the past based on the concept of diagram (mandala). Mandala is the concept of sacred area with its border.

Kemoning's community in the past setting their area according to every corner of compass' point (pengider-ider) as a symbol of village sanctity. Every god/goddess who had a throne in the temple considered as a fortress/guardian/lord of the village. From the number of 9 corners of compass' point directing to main 3 namely Puseh temple, Bale Agung, and Dalem temple which if seen of its location crossing from village' east to the most western border of the village (location of Dalem temple). Those 3 temples wereas worship places to Trimurti (God of Brahma, Vishnu and Shiva). Later on from 3 to become 3 in one location, actually at Puseh temple when Odalan ceremony was performed in the temple, then BhataraDalem also came to Puseh temple and Arak Api temple as pralingga of Brahma God jointly had a throne in Puseh temple, after ceremony was finished then it was being returned to their temples. Later on from 3 to become one location that was in Pejenengan shrine which had many statues, including the statue of Brahma CaturMuka, statue of Pasupati/Shiva, and statue which broughtkamandanu that the author predicted it was the statue of Vishnu God. So it became one power. And the last one was the existence of Padmasana shrine as the throne of Acintya (the highest one), he who was intangible, the universe. The concept of RwaBhineda (two but different namely padmasana and saptapatala) existed in Puseh temple and other temples. In addition there were small shrines in every corner of the village, built by Kemoning's ancestors in the past. It was this which being named the concept of Shiva Sidhanta (god's rule of procedure) in which Shiva God as its center. All elements of god's manifestation was existed, but Kemoning's community focused on Shiva God (Shiva Sidhanta). It was proven when Shiva priest conducted the ceremony if there was a feast day, and the phallus artifacts were found in the temples at Kemoning. Berikut skema pura pengider-ider di Desa Adat Kemoning. Following are the scheme of temples of pengder-ider in region of traditional village of Kemoning.

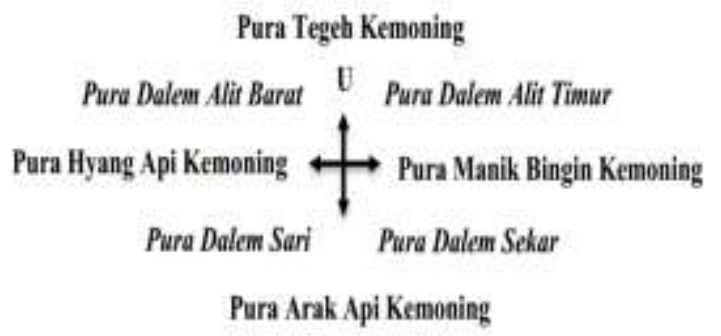

Petingar temple is the temple where people ask for healing for their sick cattle. The presence of BhataraPed shrine is where people ask for safety if there is geringagung (many sick persons). Also there is Melanting shrine (market goddess) to ask for fortune in the northeastern part of the village.

Kemoning's community is agrarian ancient community, with the presence of UlunSuwi temple, Masceti, shrine of Ulun Danu, DalemBalingkang, etc. There is angupadesa 
(god getting around villages/rice fields) brings safety to all the community and region. Long time ago there was a ngusabanini, the presence of Bhatara Sri at BalaiAgung temple, statue of Dewi Sri and Vishnu God also exist in Puseh temple. There is a stretching wide rice field up to the most southern border of the village, the presence of subak and pekaseh. There are rivers at the center/ around the village to irrigate the field/farm. There are ceremonies of Dewi Sri (mebiukukung, etc.). And also there are stone mortars to process the paddy. In addition there are also stone barrels as ancient village tools. There are also pillars (umpak-umpak) of ancient houses being found.

One of the proofs that Kemoning village is an ancient village about the era of Ancient Bali, namely with the presence of shrines of DalemBalingkang and Ulundanu. It means that worshipping direction of Kemoning's community in the past was directed to the west to the area of kingdom of Udayana. So the existence of Kemoning's people had been presence before the kingdom of Gelgel existed. Later the group of Pasek came to Kemoning to set new life after Bali was defeated by Majapahit. At that time was the beginning of Gelgel kingdom era. This pasek group cooperated with the next group in establishing the building of the grand temple. For example between ancient statues at Puseh temple is in different time with the era of constructing the temple, the statues were made earlier than the temple.

Supporting walls is equipped with paduraksa which towering high and many in number, almost every temple have great/grand gates, and candibentar (symmetrical arches). The walls have ornament of puppet reliefs (epic of Maha-bharata/Ramayana). Walls' ornaments are great/grand/full of art.

Magical stone artifacts/prehistoric tradition is spreading almost in every temple located in the village such as Puseh temple, Dalem temple, Arak Apitemple, Uluwatu temple, Tegeh temple, Petinggar temple, and HyangApi temple. Artifacts of creese and copper inscription are presence in the house of the elders/head of the village. Palm leaves inscription exists in Puseh temple. To understand everything about this village there is also the source of awig-awig and village monograph. Besides that Kemoning village also has a set of ancient gong and magical (sounds very loud).

Kinship between clients in Kemoning cultural village and its spread up to another region, shows the important role of this village in the kingdom era in the past. All the description above shows how big the ancientness content owned by Kemoning cultural village.

\section{CONCLUSION}

Kemoning cultural village as a place where people forms a certain community group/pakraman, which is bound/regulated of their lives by one custom, toward collective life purpose/live in society which had been applicable/ agreed since ancestors era in the past until now, and led by a head of the village/ bendesaadat. As it is known that custom's rules/collective rules are known as awig-awigdesa.

The conclusion is that pakraman of Kemoning cultural village was existed since the reign of kings from Balinese Late Antiquity era, the same era with the inscriptions of Celepik, Tojan, Gelgel, meanwhile the name of the village "Kemoning" had been known since the era of Gelgel kingdom. It means that the previous name is not known / suppressed by the next name. This previous name has been remained a thought for the author to be kept tracked, or it actually didn't have a name before. If pakraman in Kemoning area had been existed since Balinese Late Antiquity era/Balinese Early Middle era then it can be interpreted that people's lives had been started since the previous era, it is proven from a lot of magical stones in the shrines of the temples at Kemoning. It means that prehistoric tradition was still active in the next era.

The name of "Kemoning" may mean the name of tree, but also may mean "holy intention/wish". It is necessary to know that when the author was a kid, growing in the village, there were many kemuning trees, but at the later time these trees almost disappeared, and at the present time it was planted again by people as village mascot.

\section{SUGGESTION}

Cultural product contains cultural values which is implicit in it. With many artifacts left in Kemoning cultural village shows that how many cultural values which are scattered. It becomes a duty for young generation or community of Kemoning on the whole to maintain/preserve complex ancient cultural values. It should be appreciated with cultural blessing which is highly valuable. There are several cultural values that must be preserved / revived in the future, among others: ngusabanini needed to be revived. Several things that must be preserved are various agrarian cultural values such as ceremonies for Dewi Sri which is now increasingly fading away due to the lack of agricultural land. It is blessing for the reviving of tradition ngupadesa by accompanying the god circling around village area. Bless and preserve various ancient dances, especially for the requirement of religious ceremonies. Preserve the tradition of ngayah in the temple either by jointly clean the temple/village area, or the form of togetherness / village mutual cooperation so that not to be lost its community unity. Preserve the tradition of megibung (eat together) so that kinship is still maintained. Young generation nurseries hopefully goes well either in sekahatrunatruni, mekidung/mewirama, pesraman, lecture/spiritual guidance for public/young generation. To create the form of community education so that it is open to advancement and able to compete with other community. To give training so that community is able to carryon their lives in line with the progress of time.

The village leaders hopefully are able to prepare / render the village as a place to prosper the society, to form village area to have economic value so that the life of the people becomes easy. 


\section{ACKNOWLEDGMENT}

I would like to express my gratitude to all parties, especially Udayana University (LPPM), Fakulty of Arts, for the support financially and moraly from the begining of the research until this process is completed.

\section{REFERENCES}

Ardana, I Gusti Gede 1971 Understanding of Temples in Bali, Project of Maintaining and Developing the Culture of Bali region.

Ardana, I Gusti Gede 1982 History of Development of Hinduism in Bali, Denpasar.

Ardika, I Wayan 2004 Management of Cultural Heritage, Material Collection: Innovative Program of TOT (Training of Trainer), Conservation of Balinese Cultural Heritage in Empowerment of Balinese Cultural Heritage Preservation Agency (Bali Heritage Trust).

Dradjat, HariUntoro 1995 "Management of Cultural Resource", in the Bulletin of Cultural Heritage: Preservation of Cultural Heritage Artifacts and Effort to Nation Intelligence Building (I) 1: 3 Jakarta: Directorate of Protection and Coaching of Historic and Ancient Artifacts.

GopinathaRao, TA 1971 Element of Balinese Iconography no.11, part. II, Daw Printing House, Bombay

Goris R. 1938 Condition of Temples in Bali, printed by IHD Denpasar.

Goris R. $1948 \quad$ History of Ancient Bali, Bali Printing, Singaraja.

Goris R. $1974 \quad$ Sects in Bali, Bhratara Jakarta.

Kempers, A.J. Bernet 1959 Ancient Indonesian Art, Harvard University Press, Cambridge, Massachusetts.

Kempers, A.J. Bernet 1960 Ancient Bali, BalaiBukuIktiar, Jakarta.

Koentjoroningrat 1977 Research Methods in the Society, PT. Gramedia, Jakarta

Koentjoroningrat 1980 Human and Culture in Indonesia, jambatan, Jakarta.

Moleong, Lexy J. 2005 Qualitative Research Methodology, Bandung: RemajaRosdakarya.

Miles, MB and A.M. Huberman 1992 UI Press, Qualitative Data Analysis, Jakarta.

Soekmono, R.1963 Ancient Science and History of Indonesia, MISI Volume I, page.

159-169.

Stutterheim, W.F. Oudheden van Bali, translation by I GustiNgurahTjakra, Hotel DirgaPura, Denpasar. 